ЛОПАТА Любовь Андреевна - бакалавр факультета социологии и политологии Финансового университета при Правительстве РФ (125993, Россия, г. Москва, ГСП-3, Ленинградский пр-кт, 49; dolsher@outlook.com)

\title{
COVID-19 КАК ПОЛИТИЧЕСКИЙ ТРИГГЕР
}

Аннотация. В контексте стоящей на повестке дня пандемии коронавируса автор рассматривает модель либерального общества массового потребления Европы, которая оказалась не готовой к такому вызову, как пандемия вируса, и приводит сравнение с ситуацией в Китае, где сумели пережить этот кризис. $B$ статье COVID-19 рассматривается как политический триггер.

Ключевые слова: коронавирус, COVID-19, Китай, Европа, популизм, общественная активность, политические триггеры

$\mathrm{H}$ овый, 2020 г. начался с тревожных новостей из Китая о вспышке неизвестной болезни, которую впоследствии ВОЗ обозначила как коронавирусную инфекцию COVID-19. На сегодняшний день ее распространение приобрело масштаб пандемии, она стала глобальной проблемой человечества. С самого начала история воспринималась людьми с разной степенью равнодушия: кто-то смотрел редкие новости о ситуации в Китае с долей сочувствия к людям, кто-то - с цинизмом, кто-то и вовсе не понимал, отчего это должно касаться именно его, когда вирус «так далеко». Реакция была разной, но подавляющее большинство вряд ли могло представить, что в кратчайшие сроки COVID-19 будет объявлен пандемией. В некотором смысле то, как Китай первым пытался обуздать распространение вируса, должно было дать остальному миру некую отсрочку, чтобы подготовиться. Но воспользовались ею в весьма недостаточной мере.

В итоге, когда вирус добрался до стран Европы, последствия этой ошибки оказались страшными: в кратчайшие сроки страны накрыло коронавирусом, а число погибших в Италии превысило число умерших в Китае (при меньшем числе заболевших $\left.{ }^{1}\right)$.

Почему же Китай сумел за пару месяцев пережить кризис и начать процесс восстановления, пока Европа, в частности Италия, серьезно не оценила опасность надвигающейся катастрофы? Объяснений этому масса - и вполне научных, и лежащих в области конспирологии. Фактически мы можем воочию наблюдать, как модель либерального общества массового потребления, которая сложилась в европейских странах, оказалась совершенно не готовой к такому вызову, как новая коронавирусная инфекция. Эффективность свою то или иное общество, та или иная политическая система доказывают степенью действенности реакции на те или иные внешние вызовы и риски, с которыми они неожиданно сталкиваются.

Почему китайская модель оказалась эффективнее в борьбе с коронавирусом? Фактор первый: Китай сработал на жестком, мобилизационном административном ресурсе. Дисциплина китайцев, напрямую связанная с их менталитетом, не удивительна: если партия сказала сидеть дома или идти сдавать анализы, население покорно последует указаниям, потому что знает, что так будет правильнее для всех. Китайцы - люди «мы», а не «я», как в либеральных обществах, где в фокусе индивидуальность человека, его права и свободы. Фактор второй: правительство Китая жестко реагировало на любые фейки и поручало полиции даже проверять видеоматериалы въезжающих из-за границы видеоблогеров, чтобы те не распространяли панику. Правительство оперативно пере-

\footnotetext{
${ }^{1}$ На момент написания статьи.
} 
крыло дороги, закрыло города, препятствуя беспорядочному перемещению людей. Таким образом, азиатские страны показали высокую эффективность в противостоянии этой болезни.

Что касается Европы, то общество данной модели столкнулось с обратной стороной демократических свобод - толерантностью, ценностью свободной жизни и всеобщей независимости. В этих странах политики и культурные деятели давно возвели в культ идею «я». Очень показательна ситуация, когда люди вполне серьезно роптали на первые, почти робкие сдерживающие меры европейских правительств, аргументируя это тем, что никто не имеет права ограничивать их перемещение. При этом паника усиливалась, обрастая теориями заговора, фейками, почти апокалиптическими предсказаниями о голоде, мошенническими схемами. В Европе люди оказались не готовыми к такому кризису: правительства оказались не способными использовать механику жесткого государственного управления, а граждане не привыкли выполнять такие решения. Отсюда - невыполнение условий карантина и в соответствующей мере увеличивающееся число заболевших и умерших.

Одной из важнейших сторон данного феномена является общественная активность: ее масштабы оказались огромными. На повестке дня практически везде COVID-19 и его последствия. Сейчас, в год стремительных темпов цифровизации, когда СМИ и социальные сети пронизывают все сферы жизни людей всех возрастов, наилучшим образом видна разница между пандемией коронавируса и пандемиями, например, птичьего и свиного гриппа. Информация достигает всех и каждого, окружает со всех сторон и пугает людей. На самом деле, так действует именно это давление и форменное «информационное удушье», а не сама болезнь, которая в большинстве случаев протекает вполне безобидно. К тому же людей пугает неспособность предсказать, что будет завтра. Происходящее сейчас чрезвычайно важно исследовать с точки зрения причинно-следственных связей проявления взрывной общественной активности, ведь всеобщее внимание к проблеме - это одно, но паника, хаос и смута - совершенно другое.

COVID-19 определенно сработал как политический триггер ${ }^{1}$, который по, своей сути, воздействует на подавляющее большинство, возбуждает первичные инстинкты и работает на механизмах отвращения, страха и ограниченности времени. Говоря об общественной активности, заметно, что пристальное внимание населения обращено на состояние системы здравоохранения в своих странах и на эффективность проводимой государством политики в этом направлении. Как итог, политики и многие их действия подвергаются жесткой критике. Внимание населения приковано к официальным каналам, статистике заболеваний и смертности, активному обсуждению происходящего в социальных сетях.

Фактические последствия воздействия политических триггеров, в отличие от тех, механизмы которых известны по исследованиям в медицине (травма-триггеры) и маркетинге (триггеры продаж), как правило, крайне непредсказуемы. Именно поэтому их эффект всегда необходимо изучать со всей серьезностью, апеллируя к множеству факторов - от менталитета населения до особенностей экономической системы государства, чтобы просчитывать последствия и нивелировать худшие из них. Такой масштаб общественной реакции объясняется еще и тем, что люди яростно обсуждают не столько сам вирус, сколько причины его возникновения: одни верят в биологическое оружие «из пробирки», другие

1 Политический триггер (с англ. - спусковой крючок) - это событие или высказывание, действующее как импульс, бессознательно стимулирующий к политическому действию и воспринимаемый как на рациональном, так и на эмоциональном уровне. 
- в естественное течение событий и неотвратимую эволюцию вирусов, третьи же абсолютно уверены, что вируса не существует и все происходящее - теория заговора фармацевтических компаний.

Очень важно понимать, почему большинство государств Европы оказалось в состоянии управленческого полупаралича и информационной аномии перед лицом пандемии. Некоторые полагают, что таким образом страны Европы платят высокую цену за тот либеральный комфорт, к которому они привыкли. В Китае же ситуация была под жестким контролем. Результаты использования такой, по сути мобилизационной модели принесли результаты - число выздоровевших растет, а экономика вновь набирает обороты.

В контексте той трагической хаотизации жизни, что разворачивается в Европе, необходимо делать выводы. Это касается и либеральной популистской политики, и заигрываний с электоратом, и неспособности контролировать взрывную общественную активность.

LOPATA Lyubov' Andreevna, Bachelor of the Faculty of Sociology and Political Science, Financial University under the Government of the Russian Federation (49 Leningradsky Ave, GSP-3, Moscow, Russia, 125993; dolsher@outlook.com)

\section{COVID-19 AS A POLITICAL TRIGGER}

Abstract. In the context of the coronavirus pandemic being on the agenda, the author examines the model of a liberal mass consumptive society in Europe, which in fact is not ready for such a challenge as pandemic, and compares it with the situation in China, where they managed to weather this crisis. The author considers COVID-19 as a political trigger.

Keywords: coronavirus, COVID-19, China, Europe, populism, social activity, political triggers 